\title{
Traditional and New Media Convergence on Philippine Noontime Show, Eat Bulaga
}

\author{
Genina Mariel M. Arceo ${ }^{1, *}$ \\ ${ }^{1}$ Communciation, Adamson University, Manila, Philippines
}

\begin{abstract}
The Philippines is still moving towards the direction of merging Traditional and New Media. Some TV formats had been affected by the rise of social media although a big part of the Filipino populace is still into watching Television as their source of information. Almost all of the shows in the Philippines are available online and in mainstream television to cater viewers who wish to watch their favorite shows anytime and anywhere. Social Media Trends had helped and invaded the mainstream media on creating content for the viewers. Even social media sensations have paved its way to mainstream media by being televised on the news and segments as guests to a show. Giving these shows high ratings with an online social media star is a sign of things to come. This study is a condensed version of a research that examines how a 36-year-old noontime show being viewed by older generation has penetrated social media and has attracted younger viewers. It also aimed to know what really happen when traditional and new media integrates. Initial findings show that media convergence is absolutely more than a technology shift as most people know it.
\end{abstract}

\section{Introduction}

In July 2015, after 36 years in Philippine noontime slot, Eat Bulaga has finally found a way to penetrate social media and attract younger viewers through introduction of the AlDub segment. Eat Bulaga has captured the attention of 40 million netizens and garnered more than double the number of its household viewers in 2015. The market potential for noontime shows yet its television show viewers are relatively high considering that not everyone is watching TV during noontime [1].

Eat Bulaga is the longest running Philippine noontime show which started in 1979 and led mostly by 1960's comedians. It has been around for 36 years and its viewers have aged with the show. The show being viewed by the older generation got a boost in television viewers from Generation $\mathrm{Y}$ and the millennials, the 18 years old to late 20s generation after the noontime show brought in Maine Mendoza in one of its segment, Juan for All, all for Juan and when accidentally, the AlDub phenomenon has been created.

It is inconceivable for the millennials to take interest in Eat Bulaga as they are hooked more on their smart phones, tablets which give them instant gratification comparing to television. Noontime shows require them to sit before a television set at the time when they

* Corresponding author: geninamarielarceo@gmail.com 
are in school or at work. In fact, Eat Bulaga's social media presence pales in comparison to those of Anne Curtis and Vice Ganda, the stars in its rival noontime show, It's Showtime! [2]. But by getting Maine Mendoza, it was a game-changing move.

\subsection{The Problem}

Television has been traditionally considered to be a popular source of information and important facilitator of social interaction. Morrison and Krugman states that the television content is the conversation trigger while television is the medium that physically connects two or more people into a confined space. However, the unstoppable rise of new media allows television viewers to enjoy communal viewing experience even without being physically present. This shows that the media landscape is changing at a fast pace and moving in the direction where traditional and new media have no choice but to coexist. Given this case, this might seem to be a problem for decades long TV shows. Viewers who have aged with the show might not be as active as the young viewers are. This study hopes to determine and examine the media convergence of the oldest noontime show in the Philippines. The study asks the following questions:

a. How Philippine Noontime Shows being viewed by the older generation, have gotten a boost in television viewers from Generation Y and the millennial?

b. What happens when traditional and new media converge?

c. What are the effects of media convergence and the combination of diverse media forms?

\section{Traditional Versus New Media}

New media is changing the overall media landscape. The new media refers to content that is easily accessible via many different forms of digital media but it cannot fly as high as traditional media. It only creates things from the traditional media more powerful. New Media has no clear business model. One can be a superstar on social media but they won't earn their keep. That's what mainstream media or television has. The online digital universe especially in terms of entertainment has not yet on the level of business like that of the television.

\section{Eat Bulaga: the longest philippine noontime show}

Eat Bulaga being on the noontime slot for 36 years must have experienced all the rapidly changing media landscape on its run for years. Being on air must have been an indication that they have effectively adapted the significant change and sudden shift of media. It is evidently seen on their approach to their recent segments which entails that the show adapted the norms of digital age and cater new viewers for the show. The viral Dubsmash application was also integrated to one of Eat Bulaga's segments. But this time, the show casted one of its viral dubsmasher, Maine Mendoza for their Juan for All, all for Juan, a segment where the hosts visits villages in Metro Manila to hand out food and prizes.

\section{AIDub phenomenon}

Maine Mendoza is a superstar recruited by mainstream TV [3]. Mendoza became a Facebook sensation after she posted a compilation of her Kris Aquino Dubsmash videos. Kris Aquino is a famous television host and movie actress in the Philippines. Aquino has 
been tagged into doing horror movies in the past years that's why her famous movie lines have been used mostly by netizens in the viral Dubsmash application. According to Google Play, Dubsmash is a mobile application used to create short selfie videos while doing lip sync to famous sounds.

The "Queen of Dubsmash" tagged by netizens suddenly became part of Eat Bulaga's Juan for All, All for Juan segment. By bringing Mendoza in, Eat Bulaga has ensnared her by then a million Facebook Friends, about a million Twitter Followers and almost 100,000 YouTube subscribers to her site [4]. The Juan for All, all for Juan segment introduced the character of Mendoza as 'Yaya Dub" (Nanny Dub) still doing dubsmash. On July 16, 2015 episode, Mendoza was obviously tickled pink and could not concentrate after noticing that Alden Richards, a Filipino Actor was watching her do live impersonation on the show's live split screen. The hosts teased them and both of them played along and "flirted" with each other live on TV - this marked the beginning of the first KalyeSerye or street series in the Philippines, starring the accidental love team turned phenomenon called AlDub, a portmanteau of the tandem's character names [5]. Much to everyone's surprise, the new tandem took the internet by storm and millions of netizens continued their fascination over it. The online buzz eventually got the attention of print and radio, which fanned the AlDub romance even more.

\subsection{Kalye Serye}

Philippines has been known to many television series or what they usually called as "Teleserye" which inculcates good Filipino values and carries entertainment factor for its viewers. But \#AlDub is not your usual teleserye. It is a kalyeserye, happening right in the streets intimately familiar to our people which brought the fun out from the noontime studio into the villages and people's homes [2]. Aside from the onscreen chemistry of the two, Kalye Serye follows a no strict script and filled by Filipino values.

\section{Traditional and new media convergence}

Cheskin research explained in a 2002 report that the old idea of convergence was that all devices would converge into one single product that did everything for you. Now, these devices carry multiple functions suited to your needs. But convergence is more than this technological shift. Jenkins argued that it is a cultural shift where consumers are encouraged to seek new information, interact with one another and create new meanings of old concepts at a dispersed media.

In the realm of progressive digitalization, it has been perceived that viewers start switching to internet-based media thus, affecting the even fragmented television market. New technologies allow the viewer to change from a passive receiver of television broadcasts to an active participant [6]. The phenomenon of convergence forces broadcasters to modify the way content is constructed, both in terms of technology and concept [7].

\section{Convergence culture}

Convergence occurs within the consumers' minds, within the same devices, within the same company, and within the same fandom [7]. The consumers have more control over media consumption, production and distribution. Henry Jenkins sees that the process of convergence supports the development of a participatory culture for there is a change in the way the media is consumed. Without you knowing, it is not just the flow of content being consumed overtime but also the life, relationships, aspirations, and memories flows across 
media channels and consumed in this process. There has been a change in the way media is produced as consumers are already considered media producers themselves. Vincent Miller described in his book "Understanding Digital Culture" the producers as those that create content and cultural objects, and the consumers as the audience or purchasers of contents or objects. The blurring of the producer and consumer roles is called "prosumer" as coined by Alvin Toffler. Convergence then is not an endpoint but a process and there will be no single box that controls the flow of media into our homes [7]. The way Jenkins sees it was that the power of participation will really come from writing over the content, modding it, modifying it, expanding and adding a different perspective, then re-circulating it and feeding it back to the mainstream media. The conversation created by users creates buzz and accelerates the circulation of the media content [7]. The consumption then, as Jenkins described it, has become a collective process or what French Cyber Theorist Pierre Levy has coined as the Collective Intelligence. When all active participants or users' knowledge have been combined and published online, a certain community is created and the result of it is the collective intelligence which can be a source of alternative strength over media control and consumption.

Henry Jenkins referred to this whole transition as Convergence Culture. Jenkins described it as a cultural process where media creation and content also converges and removing the boundary on the roles of the consumer, producer, organization and the advertisers. Ready or not, we are already living in a Convergence Culture [7].

\section{Eat Bulaga versus it's showtime}

Based on the data provided by AllFamous Digital Philippines, Eat Bulaga obviously outshone its rival noontime show program, It's Showtime after taking over 96.9\% $(1,996$, 716 mentions) of the total number of online mentions from July 13 to August 13, 2015. In contrast, a mere $3.1 \%(63,451$ mentions) of these online posts came from its closest competitor. Most viewers hooked on the segment of Eat Bulaga called KalyeSerye, considers Saturday as "AlDub Day "given the fact that some of the viewers doesn't have any school or work by then. The Tweet volume for the \#AlDub hashtag continuously increases as the days passed on with still relatively million tweets for AlDuB every Saturday. The \#AlDubTamangPanahon hashtag earned a whooping of 41 million tweets surpassing the previous Aldub Twitter record of 26 million Tweets when Alden Richards visited Maine Mendoza at the mansion on September 25 as well as the 35.6 million register of 2014 Fifa World Cup semi-final match between Germany and Brazil last July 8, 2014.

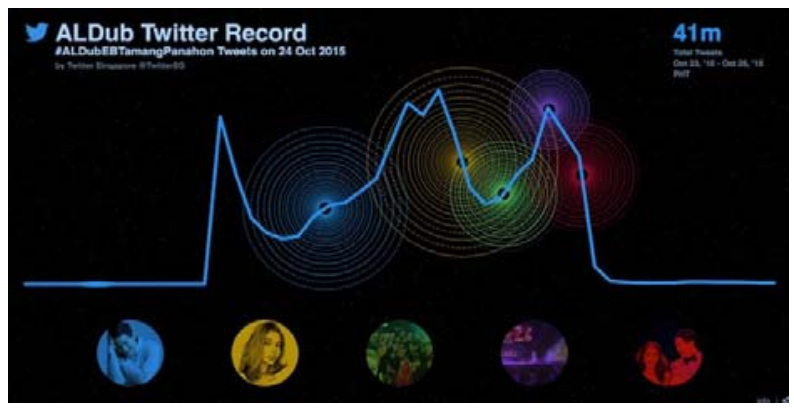

Fig. 1. ALDub Twitter Record

Fig. 1. Twitter shared that there were three peaks in the \#ALDub EBTamang Panahon conversation being the highest at more than 48,000 Tweets per minute at $2: 29 \mathrm{pm}$ on October 24, 2015 when Alden Richards sang "God Gave Me You" to Maine Mendoza and 
the couple hugged on stage in front of 55,000 fans at the charity concert. The most shared Tweet for \#ALDubEBTamangPanahon came from Mendoza which had over 74,000 Retweets and was viewed nearly 2.4 million times on Twitter.

In terms of online popularity, Eat Bulaga has now usurped It's Showtime. It Showtime had always been the netizens favorite. The churn out hashtags that reach the top trending list at noontime and the different fad produced by the hosts created funny dialogues all over the social media stream. But it seems that the tables turn quickly. The popularity of It's Showtime on the Internet fizzled during the week the AlDub love team was born [5].

Eat Bulaga is not just successful in social media but also in the television landscape with high ratings compared to their rival program. Prior to the \#AlDub, the popular belief is that the CDE television market - the same audience claimed by Eat Bulaga - isn't as immersed in social media as other market segments [2]. But the AlDub Phenomenon set it straight and prove that the $\mathrm{CDE}$ are in fact online as well into sharing and watching videos of AlDub.

\section{Theoretical framework and methodology}

Henry Jenkins describes convergence culture as the by-product of the collision between traditional and new media. Jenkins identified this as the relationship between three concepts, the media convergence, the participatory culture and the collective intelligence. This study conducts a content analysis of the effects of media convergence on the noontime show, Eat Bulaga using the theory of convergence culture. This follows the narration of how participatory culture and collective intelligence emerge in one of the show's segment and created a buzz across media platforms and content creation.

\section{Discussion / Findings}

Media Convergence is the rise of user-created content. When the Dubsmash application was launched, several users have gaged themselves estatically and even mastered the art of lip syncing. Maine Mendoza is one of the many users of the application. Her hobby of making facial expressions suddenly turned into an opportunity after she has caught the attention of Eat Bulaga producers. Mendoza has been drafted to be part of the longest noontime show in the Philippines at the Juan for All, All for Juan Segment as Yaya Dub (Nanny Dub). Her character only speaks through lip syncing of famous television and movie lines, and even making exaggerated expressions. Having a somehow familiar face at that moment, the show has slightly captured the attention of the viewers.

The next day albeit accidentally, AlDub has been created and become a massive hit. This content has achieved virality and reached a higher level of engagement in accordance with the desires of social media users for the two characters to meet. Each episode, the users are waiting for this moment to happen for the two characters haven't met even before. It's only in the noontime show and live split screen where they first met. Days passed and still their desires haven't been granted, the users started to express their imagination by editing old photos of Alden and Yaya Dub looking as if they've come across with each other. It is in this way they are being media producers themselves. It is also a crowdsourcing strategy on what viewers would want to see on the next episodes. The results, a whooping top tv ratings and top trending issue worldwide when both of the characters finally meet. Henry Jenkins termed this as Participatory Culture. It is the state where the media producer and the consumer both become participants, interacting with one another to create new concepts and eventually make it happen. Now, both of them occupy the same role. But the media producer can only gather concepts into a television content 
that will be eventually offered to the viewers. The power over the received content is gradually transferred from the media producer to the viewers, who learn how to control the received content using technology [7].

The circulation of media content depends heavily on consumers' active participation [7]. The flow of this content eventually reaches several media channels. The same concept has been even adapted on several TV commercials and magazine cover shoots. Several companies adapted the concept of the characters doing dub smash acts and split screen method strengthened the content more after the advertising materials have been released. It has even more contributed to the overall flabbergasting feeling of waiting on the next progression of the content. Likewise, attracting new viewers and spurred curiosity on it. It is as if they become participants as well on the viral content and used it for marketing purposes. It supported the claim of Henry Jenkins where the media was forced to modify their content in order to garner viewers' attention.

Much information has sprouted with all the reactions of the users. This became a content worthy for the producers of the noontime show to control what and what not the users can look forward to on the next episodes. Many were curious about the real voice of Mendoza and with the budding romance between the two characters. This other information added an incentive on the consumer's' part as they begun to talk to themselves, put their hands on it and hope that the producers will deliver it the way they want it. Another term was identified by Henry Jenkins when the temporary knowledge of the user about a content was combined to other temporary knowledge of other users, it will be resulting to a community which he called as Collective Intelligence. This community is relevant and increasingly valued by the media industry because they are those who heightens and strengthens the content as the days have passed. The Collective Intelligence can be related to social communities who have actually built their own fandom.

\section{Conclusion}

Gone are the days that the audience is sitting back and enjoying shows in the television. The emergence of media convergence has made the audiences visible and has allowed participation for various channels. The nonstop comments, photo sharing, tagging, online discussion and recommendation system are associated with greater user control over media. There is a blurring line between the producer and the consumer but they have not necessarily shifted roles. Users have only been given a chance to become co-creators of the show.

Maine Mendoza has already online followers before she joined Eat Bulaga. It has gotten the attention of the Digital-savvy Millennials while at the same time retaining their loyal viewers which comprises the Generation X (34-54 years old) spreading the "AlDub" romance online and across the world. Richards and Mendoza's writing of sweet nothings on white paper to communicate to each other mimics the propensity of millennials to communicate via social media or mobile phones [4]. Sharon Ross declared in her book, beyond the box that the Millennial generation is particularly "migratory" as they are multitasking across the internet to wander and hunt down some content without them knowing it. It will be realized that the forms of participatory culture may be summarized into expression, affiliation, collaboration and circulation. Inside the participatory culture, the active users have more power than others due to their skills and desire. Growing fans of AlDub started to express their desires by producing a creative content which affiliates to other users who share the same aspirations. Thus, forming a social community where combined efforts are made to develop creative shared content and eventually escalates the media circulation. This participatory culture has also been used as a marketing strategy to join the trend and eventually led to promoting brands. The good Filipino values portrayed 
in the show flows as well along with media transmission. The convergence of traditional and new media cut across the social media classes and bridged the generation barrier. Since this is an accidental love team, people want to be part of it as witnesses of their journey. The relatable experiences of Mendoza's Characters and Richards provided the entertainment enjoyed by people across all social classes.

What happened in Eat Bulaga showed that traditional and new media results are successful in both sides when they converge. The success of the show's rejuvenation lies from the acquired new viewers of the show and the continued existence interaction with old media. The high ratings showed us that more people still turned to television as their main source of information. But like new media content, the temporary acquired and merged content being shown in the television may fall out of fad at a particular time. Likewise, the new viewers may realize that they become new customers mostly due to a different value proposition [8]. On the other hand, from the perspective of the now fans of AlDub, they will remain loyal and passionate for it even outside the noontime show.

\section{References}

1. J. Go, Is the AlDub phenomenon losing its appeal? (2016)

2. T. Cruz, Long Live the \#AlDub Nation (2015)

3. B. Abunda, Maine Mendoza is a superstar recruited by mainstream media. Retrieved from http://entertainment.inquirer.net/179041/boy-abunda-maine-mendoza-a-superstar-recruited-bymainstream-tv

4. A. D. Nocum, 'AlDub magic' - marriage of old and new media (2015)

5. P. Quimbo, AlDub : Blurring the line between traditional media and digital media (2015)

6. Kurczewska, Izabela. The Influenece of Media Convergence on Talent Show Programs. 2013

7. Jenkins, Henry. Convergence Culture: Where Old and New Media Collide. New York and London. New York University Press. (2006)

8. I. Gan, The Social Media Phenomenon that is AlDub (2015) 